\title{
回復期リハビリ病棟における運動器系疾患患者の日常生 活機能評価得点と退院先との関連
}

The relationship between Nichijo-seikastu-kino-hyoka scores and discharge destinations in patients with motor system disorders in a Kaifukuki rehabilitation ward

\section{大森美 保*1 江 守 陽子*2 日高紀久江 ${ }^{* 2}$}

Miho Omori $^{* 1}$, Yoko Emori ${ }^{* 2}$, Kikue Hidaka*2

\section{要 旨}

目的：回復期リハビリテーション病棟において, 運動器系疾患患者の日常生活機能評価得点と, 退院先との関 連および退院先に影響する要因を検討する。

方法：回復期リハビリ病棟の運動器系疾患患者 184 名を対象に, 入・退院時の日常生活機能評価得点を分析し た.

結果 : 入院時日常生活機能評価得点が 3 点以下では全員が自宅退院であった. 退院時得点は全患者の半数以上 が 0 点に改善していたが, 退院先による違いは不明確であった。退院先のうち非自宅退院となることに影響を 与える要因を検討するため, 多重ロジスティック回帰分析を行った. その結果, 家族人数 ( $\mathrm{OR}=0.428,95 \%$ CI $0.229-0.797)$ と退院時日常生活機能評価得点 $(\mathrm{OR}=1.340,95 \% \mathrm{CI} 1.046-1.716)$ が影響因子であった. 結論：入院時日常生活機能評価得点が 3 点以下は自宅群の可能性が高く, 入院時に退院先の予測が可能である ことが示唆された. また, 退院先に影響する要因は, 退院時日常生活機能評価得点と家族人数であった.

\begin{abstract}
Objective : The aims of this study were to evaluate the relationship between Nichijo-seikastu-kino-hyoka (NSKH) scores, factors that influenced these scores, and discharge destinations of the patients with motor system disorders who were treated at a Kaifukuki rehabilitation ward.

Methods : The NSKH scores of 184 patients with motor system disorders who were treated in a Kaifukuki rehabilitation ward were evaluated on admission and at the time of discharge.

Results: The subjects whose NSKH scores on admission were three or less were all discharged to their homes. The scores at discharge improved to 0 in more than $50 \%$ of the subjects, but the difference in their discharge destinations, depending on their score, was not clear. Multiple logistic regressions were performed to evaluate factors that influenced the scores when the discharge destination was not to their home, which revealed that the number of family members $(\mathrm{OR}=0.428,95 \% \mathrm{CI} 0.229-0.797)$, and NSKH scores at discharge ( $\mathrm{OR}=1.340,95 \% \mathrm{CI} 1.046-1.716)$ were influencing factors.

Conclusion: The results of this study suggest that the subjects whose NSKH score on admission was three or less were more likely to be discharged to their homes thereby indicating that their discharge destinations were predictable. The factors influencing their discharge destinations were the NSKH scores at the time of discharge and the number of family members.
\end{abstract}

Keywords : 回復期リハビリテーション病棟 (kaifukuki rehabilitation ward), 日常生活機能評価得点 (nichijo-seikastukino-hyoka scores), 退院先 (discharge destinations), 運動器疾患 (motor system disorders)

\section{緒 言}

2000 年の医療制度改革として，急性期病院の在院 日数の短縮と高齢者の自立を支援するために回復期リ ハビリテーション病棟（以下，回復期リハビリ病棟） が新設された．回復期リハビリ病棟への入院患者の原
因疾患は, 2010 年度の調査 ${ }^{1)}$ では脳血管系疾患が $49.6 \%$, 運動器系疾患が $37.5 \%$, 廃用症候群が $11.8 \%$ である。運動器系疾患は, 2001 年は $15.1 \%$ で あったが, 2002 年から 2005 年にかけて $25 \%$ 前後で推 移し，2006 年以降 30\%台へと増加してきている。一

\footnotetext{
*1 著者連絡先：大森美保 東京大学大学院工学系研究科〔⿳亠丷厂 113-8656 東京都文京区本郷 7-3-1〕 e-mail address：mh73.omr@hotmail.co.jp *2 筑波大学医学医療系
}

（受付日：2013 年 2 月 7 日，受理日：2013 年 7 月 3 日） 
方, 要介護認定を受けるに至った原因疾患のうち, 脳 血管疾患が $21.5 \%$ と最も多く, 関節疾患 $10.9 \%$, 骨 折・転倒が $10.2 \%$ であり, 運動器関連の疾患が $21.2 \%$ でった ${ }^{22}$. 高齢者の骨折の発生要因として は, 転倒によるものが多く報告されている ${ }^{3-5)}$. 特に 2008 年までの過去 10 年間では, 90 歳以上の股関節骨 折の患者が劇的に増加 ${ }^{6)}$ していることから, 運動器系 疾患の中でも骨折後の ADL の回復は, 高齢者の自立 に直結するものであり, 回復期リハビリ病棟の重要な 役割といえる.

2008 年度の診療報酬改定において回復期リハビリ 病棟の成果評価が導入され, 重症患者の受け入れ割 合, 重症患者の回復割合, 在宅復帰率の 3 点で評価す ることになった，患者評価には急性期病棟で使用され ている看護必要度 B 項目が「日常生活機能評価表」 として使用されはじめた。これまでのリハビリの評価 は主にバーセル指数 (Barthel Index : BI) や機能的 自立度評価 (Functional Independence Measure : FIM) が使用されてきたため, 日常生活機能評価による患者 評価や，この評価指標を使って退院先との関連を検討 した研究は少ない. 日常生活機能評価を使用した患者 の重症度と退院先との関連を検討することは, 回復期 リハビリ病棟の成果を示すと同時に, 急性期から回復 期, 回復期から在宅・施設への連携において意義ある ものになると考える.

本研究では, 回復期リハビリ病棟において「日常生 活機能評価表」を用いて運動器系疾患患者の評価を行 い, 日常生活機能評価と退院先との関連, および退院 先に影響する要因を検討した。

\section{研究方法}

\section{1 対象および調查期間}

$\mathrm{A}$ 病院回復期リハビリ病棟に 2007 年 7 月以降に入 院し， 2010 年 9 月までに退院した患者 539 名のう ち, 急性増悪等により一般急性期病棟に退院した患者 28 名と回復期病棟の対象外患者 2 名を除く 509 名の うち, 診療報酬算定におけるリハビリテーション分類 において運動器リハビリテーションの対象となる患者 184 名（大腿骨骨折 121 名, 骨折以外の下肢の術後 39 名, 胸腰椎疾患 14 名, その他 6 名）を分析対象とし た。

\section{2 方法}

研究デザイン：症例対照研究

調査方法：調查には看護記録・リハビリ記録を含む 診療記録を使用した。
調査内容: 患者の基本属性, 疾患名, 在院日数, 認 知症, 配偶者 (同居), 家族人数 (敷地内同居者と本 人を含めた人数), 退院時の内服管理の状況, 入 - 退 院時の日常生活機能評価得点を調査し, 「入院時得点 一退院時得点」を改善度とした。

要介護者との続柄でみた主介護者の割合は, 配偶者

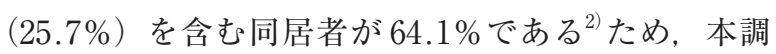
査では配偶者と同居の家族人数をそれぞれ調査した.

認知症に関しては長谷川式簡易知能評価スケールが 20 点以下を認知症有りとし, 入院期間中に複数回評 価していた場合は，退院日直近の評価とした，内服に 関しては一包化されたものを管理できている場合に自 己管理可能とした。

日常生活機能評価表の 13 項目につては看護師（総 数 26 名)が日勤で記録し, 夜勤では状態の変化があっ た場合のみ追加記録している. 日常生活機能評価表に よる評価は, 評価者研修修了証を授与されている看護 師 3 名と, その看護師による院内研修を受けた 26 名 全員の評価試験において $100 \%$ 正答が確認された状態 で実施し，評価の信頼性について担保した。

退院先については, 自宅群と非自宅群に分類した。 な打自宅打よび居住系の施設（ケアハウス・グループ ホームなど）を自宅群とし，転院または特別養護老人 ホーム, 老人保健施設, 介護療養型老人保健施設一の 退院を非自宅群として分類した. な㧍入院前よりケア ハウス, 老人保健施設一入所していた場合も, 退院先 の区別は前述の分類と同様にしている.

\section{3 分析方法}

分析対象者の基本属性については Pearson の $\chi^{2}$ 検 定と, 正規分布でなかったため Mann-Whitneyの U 検定を実施した. 日常生活機能評価得点については, 入院時・退院時の合計得点を退院先で比較した，退院 先の影響因子については, 基本属性と日常生活機能評 価得点において多重ロジスティック回帰分析を実施し た。分析にはSPSS for Windows Ver.16.0を使用 し, 有意水準を $5 \%$ 未満とした。

\section{4 倫理的配慮}

本研究は, 診療記録情報の分析である. 調查病院で ある $\mathrm{A}$ 病院の倫理委員会と著者が所属する研究機関 の研究倫理委員会の両方から承認を得ている(A 病 院承認: 平成 22 年 11 月 2 日, 大学: 承認番号 $22-$ 350 号). 


\section{結 果}

\section{1 分析対象の特性}

分析対象者の特徵を表 1 に示した。自宅群と非自宅 群を比較すると, 自宅群の平均年齢が 74.1 (中央值 $77 ： 17 \sim 98$ ) 歳に対し, 非自宅群は 82.5 (中央值 $82: 74 \sim 92)$ 歳 $(\mathrm{p}=0.021)$, 在院日数は自宅群が 42.9 (中央值 $36.5: 5 \sim 109$ ) 日で, 非自宅群が 64.7 (中 央值 $71.5: 19$ 153） 日であった $(\mathrm{p}=0.016)$. 家族 人数は自宅群の平均は 4.0 (中央值 $4.0: 1 \sim 8$ ) 人, 非自宅群の平均が 2.9 (中央值 $2.5: 1 \sim 7)$ 人 $(\mathrm{p}=$ $0.025)$, 配偶者ありは自宅群では 84 人 $(49.4 \%)$, 非 自宅群では 3 人 $(21.5 \%)$ であった $(\mathrm{p}=0.039)$.また,

内服の自己管理が可能な人は自宅群で 107 名 (97.3\%) であったが，非自宅群では 3 名 (21.4\%) であった (p $=0.003)$.

退院先別の日常生活機能評価得点は, 入院時得点で は, 自宅群は平均 3.9 (中央值 $3.0: 0 \sim 14$ ) 点, 非自 宅群は平均 8.1（中央值 $7.5: 4 \sim 15 ）$ 点であった（p $<0.001$ ). 退院時得点は自宅群の平均 1.5 (中央值 $0.0: 0 \sim 14$ ) 点, 非自宅群の平均 5.4 (中央值 $5.5: 0$ 〜11）点で, 非自宅群の方が得点が高く重症であった $(\mathrm{p}<0.001)$. 改善度は両群とも差はなく同様に改善 していた（ $\mathrm{p}=0.580 ）$.

\section{2 退院先別の日常生活機能評価得点の分布}

入院時と退院時の日常生活機能評価得点の分布を図 1 に示した。 入院時得点が 3 点以下では全員が自宅群
であったが，4点以上では自宅群と非自宅群が混在し ていた。退院時得点は半数以上が 0 点に改善してい た。

\section{3 退院先に影響を与える要因}

退院先に影響を与える要因を検討するため, 多重口 ジスティック回帰分析を行った（表2). 従属変数を 退院先とし, 独立変数は, 在院日数, 家族人数, 配偶 者の有無, 認知症, 内服管理能力, 退院時日常生活機 能評価得点の 6 要因に年齢と性別を加え, 強制投入法 を用いた. 8 要因のうち, 家族人数 $(\mathrm{OR}=0.428$, $95 \%$ CI $0.229-0.797)$ と退院時日常生活機能評価得 点 $(\mathrm{OR}=1.340,95 \% \mathrm{CI} 1.046-1.716)$ が影響因子 として示された.

\section{考 察}

\section{1 分析対象の特性}

分析対象の平均年齢は 74.8 歳, 男性 61 名 $(33.2 \%)$, 女性 123 名 $(66.8 \%)$ で, 2010 年の全国回復期リハ ビリ病棟連絡協議会の実態調查 ${ }^{1}$ の運動器系疾患患者 とほほ同様の構成であった，発症から入棟までの日数 は全国平均より 7 日長く, 在院日数は 10 日短かっ た. 自宅退院率は全国平均を $12.9 \%$ 上回っていた. 日常生活機能評価得点の入院時平均点と退院時平均点 はいずれも全国平均点より低かったが，他の運動器系 疾患に特化した回復期りハビリ病棟の報告 ${ }^{7}$ とは同様 であった，退院先別でみると，自宅群と非自宅群にお

表 1 退院先別の対象の特性と日常生活機能評価得点

\begin{tabular}{|c|c|c|c|c|}
\hline \multirow[b]{2}{*}{ 項目 } & & \multicolumn{2}{|c|}{ 平均（中央値：最小〜最大)/人数（\%） } & \multirow[b]{2}{*}{$\mathrm{p}$ 值 } \\
\hline & 全体 $n=184$ & 自宅群 $\mathrm{n}=170 \quad$ (92.4) & 非自宅群 $n=14 （ 7.6 ）$ & \\
\hline 年齢 & $74.8(78: 17 \sim 98)$ & $74.1 \quad(77: 17 \sim 98)$ & 82.5 (82: 74 92) & 0.021 \\
\hline 性別 & $61(33.2)$ & $57(33.5)$ & $4(28.6)$ & 0.478 \\
\hline 女性 & $123(66.8)$ & $113(66.5)$ & $10(71.4)$ & \\
\hline 発症から入棟までの日数 & $34.3(30.0: 6 \sim 106)$ & $33.9(30.0: 6 \sim 94)$ & $39.1 \quad(36.0: 16 \sim 106)$ & 0.468 \\
\hline 在院日数 & $44.6(38.0: 5 \sim 153)$ & $42.9(36.5: 5 \sim 109)$ & $64.7(71.5: 19 \sim 153)$ & 0.016 \\
\hline 家族人数 & $3.8(4.0: 1 \sim 8)$ & $4.0(4.0: 1 \sim 8)$ & $2.9(2.5: 1 \sim 7)$ & 0.025 \\
\hline 配偶者 & $87(47.3)$ & $84(49.4)$ & $3(21.4)$ & 0.039 \\
\hline 無 & $97(52.7)$ & $86(50.6)$ & $11(78.6)$ & \\
\hline 認知症 & $45(28.1)$ & $39(26.4)$ & $6(50.0)$ & 0.082 \\
\hline 無 & $\begin{array}{c}115 \text { (71.9) } \\
(\text { 不明 24) }\end{array}$ & 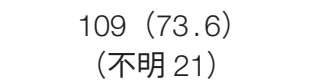 & $\begin{array}{l}6(50.0) \\
(\text { 不明 3) }\end{array}$ & \\
\hline 内服管理 & $110(59.8)$ & $107(62.9)$ & $3(21.4)$ & 0.003 \\
\hline 不可 & $74(40.2)$ & $63(37.1)$ & $11(78.6)$ & \\
\hline 日常生活機能評価得点 & & & & \\
\hline 入院時 & $4.2(4.0: 0 \sim 15)$ & $3.9(3.0: 0 \sim 14)$ & $8.1(7.5: 4 \sim 15)$ & $<0.001$ \\
\hline 退院時 & $1.8(0.0: 0 \sim 14)$ & $1.5(0.0: 0 \sim 14)$ & $5.4(5.5: 0 \sim 11)$ & $<0.001$ \\
\hline 改善度 & $2.4(2.0:-3 \sim 11)$ & $2.4(2.0:-3 \sim 11)$ & $2.6(3.0:-1 \sim 6)$ & 0.580 \\
\hline
\end{tabular}

性別, 発症回数, 配偶者, 認知症, 内服管理は Pearson の $\chi^{2}$ 乗検定, その他は Mann-Whitney の U 検定を実施 


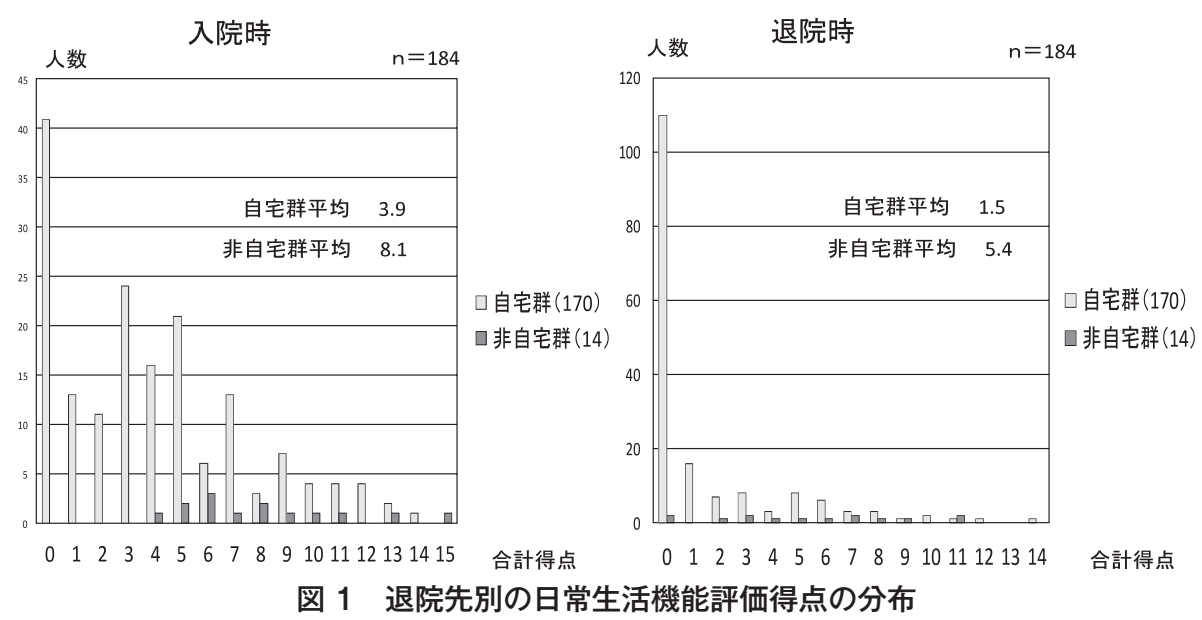

表 2 非自宅退院に影響する要因

\begin{tabular}{|c|c|c|c|}
\hline 独立変数 & オッズ比 & 95\%信頼区間 & $\mathrm{p}$ 值 \\
\hline 年齢 & 1.064 & $0.977-1.158$ & 0.154 \\
\hline 性別（0：男性，1：女性） & 0.273 & $0.048-1.554$ & 0.143 \\
\hline 在院日数 & 1.011 & $0.983-1.039$ & 0.435 \\
\hline 家族人数 & 0.428 & $0.229-0.797$ & 0.008 \\
\hline 配偶者（0：有, 1：無） & 2.082 & $0.377-11.514$ & 0.400 \\
\hline 認知症（0：有, 1：無） & 3.845 & $0.556-26.597$ & 0.172 \\
\hline 内服管理（0：可, 1：不可） & 2.929 & $0.345-24.846$ & 0.325 \\
\hline 退院時日常生活機能評価得点 & 1.340 & $1.046-1.716$ & 0.021 \\
\hline
\end{tabular}

多重ロジスティック回帰分析（強制投入法） 従属変数：退院先（0：自宅 1 : 非自宅）
モデル $\chi^{2}$ 検定 $p<0.001$

判別的中率 $91.3 \%$

Hosmer と Lemeshow の検定 $p=0.649$
いて有意差があったのは, 年齢, 在院日数, 家族人 数, 配偶者, 内服管理であった。発症から入棟までの 日数と在院日数については, 非自宅群の方が長かった が，急性期から回復期への移行までに時間を要した対 象者は重症である可能性が高く, そのためリハビリ期 間も長期化したと考えられる。また常用薬の服用に伴 う内服の自己管理は重要であり，これが不可能な場合 は非自宅群の可能性が高くなると考えられる。

\section{2 日常生活機能評価得点}

日常生活機能評価得点は, 入院時 - 退院時ともに非 自宅群の方が高く，重症であった，改善度については 両群とも同程度の改善があった. 分布表でみると入院 時得点 3 点以下では全員が自宅群となり, 入院時 4 点 が退院先を決定する一要因と考えられた。

一方, 退院時得点では自宅群と非自宅群の境界は明 確ではなかった。退院時に日常生活機能評価得点が 3 点以下であるのに, 男性 2 名, 女性 3 名の 5 名は非自 宅群であった。このうち男性 1 名（82 歳）は回復期 リハビリ病棟の入院日数が満期となったが, 治療上の
理由で入院リハビリの継続が必要とされたため療養病 棟へ移動した。他の 1 名（82 歳）は長男との二人暮 らしで，本人は自宅退院を希望したが長男の意向（心 配）で施設入所となった，女性 3 名は全員が 80 歳代 の一人暮らしであり, 1 名は認知症があり受傷前から 入所していた施設へ退院した，退院時の得点が低くて もこうした介護者の有無 ${ }^{8}$, 家族背景や家族の意思 ${ }^{9)}$ などの社会的な要因で非自宅群となるケースが存在し た. 運動器系疾患は高齢者に多いため夫婦が健在して いる可能性が低く，日本人の平均寿命を考えると高龄 女性の一人暮らしである可能性が高いと思われる.

\section{3 退院先に影響を与える要因}

退院先に影響を及ぼす要因の多重ロジスティック回 帰分析では，家族人数，日常生活機能評価得点が影響 要因であるといえた．家族人数が多いほど在宅での介 護力が大きいことが推察され, 自宅群の可能性が高く なるとが考えられた。独居者（17名）に限った退院 先別の退院時日常生活機能評価得点では, 17 名中 13 名 $(76.5 \%)$ が自宅群で，そのうち 0 点が 11 名， 1 
点が 1 名, 2 点が 1 名で, 非自宅群となった 4 名は, 0 点, 2 点, 3 点, 4 点が各 1 名ずつであった. このこ とは, 独居者は退院時日常活機能評価得点が 0 点であ れば自宅群の可能性が高くなると考えられた.

\section{研究の限界}

1. 今回の調查結果は 1 病棟のデータであること, 非 自宅群の数が少ないことにより，一般的なデータとし ての活用は難しい.

2. 診療記録による調査であるため, 記録されていな い内容についてはデータが得られないものがあった。

3. 日常生活機能評価得点による分析をしたが, 日常 生活機能の各項目と退院先との関連についての検討が 必要である.

4. 退院先への影響因子として, 患者と介護者との関 係までは検討していないため, 家族人数と退院先との 関連は明確ではない．また居住地の環境や介護保険等 の地域リソースなどの環境要因については考慮してい ない.

\section{結 論}

運動器系疾患患者の日常生活機能評価と退院先との 関連について検討した結果，入院時日常生活機能評価 得点が 3 点以下は自宅群の可能性が高く, 入院時に退 院先の予測が可能であることが示唆された。しかし退 院時の得点については, 得点が低い方が自宅群の可能 性は高いといえるが，基準点は明らかにならなかっ た。また，退院先に影響する要因は，退院時日常生活 機能評価得点と家族人数であった.

\section{文 献}

1）全国回復期リハビリテーション病棟連絡協議会. 回復 期リハビリテーション病棟の現状と課題に関する調查 報告書. 国立保健医療科学院施設科学部. 平成 23 年 2 月, $100 \mathrm{p}$.

2）厚生労働省大臣官房統計情報部．国民生活基礎調查 平成 22 年 第 1 巻 結果の概要. 厚生労働統計協会. 2012, 758p.

3）大畑浩, 他. 高齢者における転倒発生状況と関連要因 (第4 報). 高知市医師会医学雑誌. 2006, vol. 11, no. 1 , p.70-75

4）福島斉, 他. 高齢者大腿骨近位部骨折患者の転倒原因 調查 内的要因と外的要因に注目して. 整形外科. 2012, vol. 63, no. 10, p. 1021-1026.

5）稲田光範，他．大腿骨頚部骨折患者に抢ける転倒状況 の調查. 高松市民病院雑誌. 2001, vol. 17, p. 62-64.

6) Hagino $\mathrm{H}$, et al. Nationwide one-decade survey of hip fractures in Japan. J Orthop Sci. 2010, vol. 15, no. 6, p. 737-745.

7）本間毅，他．当院における運動器疾患に特化した回復 期リハビリテーション病棟の短期成績と問題点. 日本 臨床整形外科学会誌. 2010 , vol. 35 , no. 3, p. 187189.

8）菊池一美, 他. 当院回復期リハビリテーション病棟に おける大腿骨近位部骨折患者の自宅復帰に影響する因 子の検討. 秋田理学療法. 2010, vol. 18, no. 1, p. 39-41.

9）碇谷真帆，他. 回復期病棟から施設入所となった患者 背景を探る 患者の意向に反した 4 事例から. 日本リ ハビリテーション看護学会学術大会集録 16 回. 2004, p. 185-187. 